\title{
CREATIVITY BASED ON NEW TECHNOLOGIES IN DESIGN OF AGE-FRIENDLY CITIES: POLISH SENIORS ABOUT THEIR NEEDS - RESEARCH REFLECTION
}

\author{
Grzegorz DUTKA (D) ${ }^{1}$, Grzegorz GAWRON (D) ${ }^{2,}{ }^{*}$, Paulina ROJEK-ADAMEK (D) ${ }^{3}$ \\ ${ }^{1,3}$ Institute of Philosophy and Sociology, Faculty of Social Sciences, Pedagogical University of Cracow, \\ Ul. Podchorażych 2, 30-084 Cracow, Poland \\ ${ }^{2}$ Institute of Sociology, Faculty of Social Sciences, University of Silesia in Katowice, Bankowa 11, \\ 40-007 Katowice, Poland
}

Received 22 September 2020; accepted 13 May 2021

\begin{abstract}
The identified changes in age structure on a global and local scale pose a major challenge for modern societies. And so, the issue of adapting urban spaces to the needs of older people has become of particular interest. But the intensity of changes requires a creative approach to this matter. One of the responses to this phenomenon has been the World Health Organization proposal to build age-friendly cities and communities. It details how to effectively reduce social and spatial exclusion experienced by older people. Importantly, the needs of the elderly are increasingly being taken into consideration during the design process. This article provides the theoretical explanation of the issues related to the creative solutions based on new technologies in the perspective of building an age-friendly city. The empirical section presents selected survey results conducted among Polish seniors which focus on three main aspects of new technologies: the current importance for seniors; the current state of solutions in the city; the predicted importance in the future.
\end{abstract}

Keywords: age-friendly cities, ageing, design, new technologies, seniors.

\section{Introduction}

Every year, new projects and concepts are created around the world to support older people on various levels of their daily life. One initiative is the concept of age-friendly cities and communities (AFCCs), developed in 2007 by World Health Organization (WHO). It is expressed primarily in the design and re-design of urban space to best meet the needs of senior users. To this end it is nearly synonymous with the fundamental tenets guiding the creators of social design trends, known as universal design/design for all/ inclusive design. The AFCCs and universal design/design for all/inclusive design spawned out of the dynamics of demographic changes taking place in contemporary societies and their socio-economic consequences. Although each of these concepts has its own language, in reality they all center

*Corresponding author. E-mail: grzegorz.gawron@us.edu.pl 
around the need to design the material world so that it responds best to the changing needs of individuals. We only experience what is accessible to our senses, body and mind. Thus, human beings mental and physical constitution act as filters that condition the phenomena we can experience and the way we do it. Furthermore, human constitution also acts as a generator of phenomena; because through our experience we add qualities to objects (de la Fuente Suárez, 2013, p. 2). It is inevitable to confront our needs on each stage of life, with the rather rigid architectural structure of the city and other elements of the urban surroundings. The value of these places (architecture, buildings, spaces, etc.) and their perception expresses their degree of adaptation to the needs of users. Therefore, it is a way of arranging and consolidating in their characteristics the answers to questions about the basic expectations of recipients (residents). The results of this process are conditioned by adaptive possibilities (architectural, financial, technical, functional, aesthetic, logistic, ownership, etc.), the reservoir of which is often limited (Gawron \& Rojek-Adamek, 2017). Therefore, we should not only be interested in designing solutions for individuals or one specific group of recipients, e.g. the elderly, but about seeking solutions to satisfy the needs of different users.

It is assumed that the most problematic is the societal resistance to the technological solutions, especially mostly associated with group of seniors. Despite that, seniors are more and more often willing to adopt solutions that help them better monitor their medical systems, and maintain social relations. Upon recognition of this, society has seen an increase in proposals for the systematic implementation of new technological solutions to these ends. Research shows that despite the deterioration of cognition coming from the onset of old age, seniors, in their readiness to learn new skills and experiences in dealing with information and communication technology (ICT) are comparable with users in other age groups (Broady et al., 2010). Applications of design and technology have the potential to greatly contribute to independent living and lifestyle support and can compensate for functional deficits associated with ageing (van der Cammen et al., 2017, p. 11). If inadequate research exists on this front, then essentially the elderly segment of society is at the mercy of guesswork when it comes to how they will or will not be included in society.

Contemporary age-friendly cities should also be places in which technological solutions expand the concept of "friendliness". Therefore, the main purpose of the article will be to show the significance and potential use of new technologies in various areas important for modeling senior-friendly cities. This will be done by presenting results from the survey of the expectations and demand for such solutions by the Polish elderly.

\section{Theoretical framework}

\subsection{New technologies in elderly life}

According to European Commission Eurostat data in 2009 about 24\% of people aged 65 and older, living in the European Union (EU) used the Internet. But in the last decade, the situation has changed a lot. In 2019 regular Internet users comprise about $63 \%$ of that same demographic in the EU. However, there is a wide variance among EU member states. Countries such as: Denmark, Netherlands and Luxembourg saw the highest level of Internet use by individuals at $84-90 \%$, while in countries such as: Bulgaria, Greece and Portugal, 
the level reached only 23-34\%. And, in Poland, the use of Internet by inhabitants aged 65+ is comparatively low at only $40 \%$ (Eurostat, 2020). This says that while the first level of the digital divide - inequalities in Internet access - has been significantly reduced across Europe in the last decade, the second and third level of the age-related digital divide - inequalities in competence and performance - are still prevalent (Gallistl et al., 2020, p. 233).

With the trend of an ageing global population, there has been an increase in the research of the digitizing of senior life (Schulz et al., 2015; Wagner et al., 2010; Wilson, 2018). They show that Internet's potential to bring many benefits to users, and especially older people. Virtual connection allows elderly users to improve their relationships, e.g. older people with limited mobility and whose relatives live afar can maintain communication and thus avoid social exclusion. Despite the promise and potential of the Internet to ameliorate much of the social exclusion that exists, the elderly still have some reservations when it comes to adopting it, but those reservations are diminishing (Carpenter \& Buday, 2007; Chiu \& Liu, 2017; Cody et al., 1999; Hogeboom et al., 2010; Shapira et al., 2007; Taha et al., 2009). Published analyses illustrate the newer technologies are, the more seniors tend to avoid them. This can be characterized by anxiety, frustration with interface platforms, and a general negative attitude toward new technology, and not least of all, higher online security concerns (Cattaneo et al., 2016; Damodaran et al., 2013; Gallistl et al., 2020; Hussain et al., 2017; Kamin et al., 2017; Reisdorf \& Groselj, 2017). The results of previous research also emphasize the importance of health-related barriers when accessing new technologies, e.g. using the Internet is more challenging for those with deteriorating eyesight, shaky hands, or (mild) cognitive impairment (Charness \& Boot, 2009; Damodaran et al., 2013; Gallistl et al., 2020; Hussain et al., 2017; Lee et al., 2011). Furthermore, researchers have identified multiple socio-economic factors as predictors of elderly Internet use. Low education and income are identified as the main factors limiting Internet use in later life (Charness \& Boot, 2009; Gallistl et al., 2020; Lelkes, 2013; Barbosa Neves \& Amaro, 2012; Barbosa Neves et al., 2013).

A fundamental requirement of adapting to a modern society is the ability and willingness to continuously learn. To accomplish this, a citizen must be cable of physically using that technology in its designed interface. Some analyses revealed products to be often poorly designed for older adults and therefore uncomfortable or at times even unfeasible for use (Charness \& Boot, 2009; Czaja et al., 2019; Gallistl et al., 2020).

A major ascertainment from this analysis is how important and what an immense impact technological and creative design solutions have on any member of society as they age and continue to integrate in their respective societies. Some analyses revealed products to be often poorly designed for older adults and therefore uncomfortable or at times even unfeasible in their intended use (Charness \& Boot, 2009; Czaja et al., 2019; Gallistl et al., 2020). An important requirement of living in modern societies is continuous learning in order to adapt to the changes that occur in life, constantly gaining capabilities to function in a changing reality and it is believed that older adults' involvement in the Internet facilitate this (Chiu \& Liu, 2017; Friemel, 2016; Lifshitz et al., 2018; Nimrod, 2014).

As identified by Wanka and Gallistl (2018), who developed the concept of material praxeology of ageing with technologies, this concept assumes the use of (or lack of) new technologies by the elderly is not purely dependent on the individual's attitude and aptitude, 
but also their social and physical environment. These authors argue that it is the weave of interaction with other members of society (relatives, friends, other members of the community, officials, etc.) and physical conditions (especially technological devices) which have a decisive impact on how seniors find themselves adapting to a changing reality (Gallistl et al., 2020, p. 234). A valuable conceptual framework for this type of research is the AFCCs concept. As we will see below, this idea accounts for the broad context of conditions that ultimately make the city friendly to the elderly. In this perspective of urban environment design, the widespread use of new technologies can significantly limit the social exclusion of older people, and thus increase in their social participation.

\subsection{Age-friendly cities and communities and age-friendly design}

Government institutions and organizations from different countries have been supporting active ageing policies for years and have also been promoting the design of elderly-friendly housing areas. Some of these initiatives take the form of national or regional programs, but more and more are being achieved through the WHO - AFCC. The model of AFCCs was conceived in 2007 (World Health Organization, 2007) but its creation was preceded by a number of policy initiatives launched by the WHO during the 1990s and early 2000s (Buffel et al., 2012, p. 599). This model attracted great interest of the proponents of the active ageing movement, and in 2010, developed into the WHO Global Network of Age-Friendly Cities and Communities. This network currently includes 1000 cities and communities in 41 countries, covering over 240 million people worldwide (World Health Organization, 2021). Global Age-Friendly Cities: A Guide (World Health Organization, 2007) has identified eight domains of city life: outdoor spaces and buildings; transportation; housing; social participation; respect and social inclusion; civic participation and employment; communication and information; and community support and health services (World Health Organization, 2007, p. 8).

This model is extremely flexible in that it supports planners and designers in their efforts to maintain consistency with respect to the demographics of their particular environment.

Demographic changes compel urban policy planners to take into account the AFCCs approach, they also afford a wide range of opportunities to designers contributing towards solving selected social problems with a socially responsible and creative approach to design. This trend is defined in literature as universal design, design for all (Mace et al., 1980; Mace, 1998) or inclusive design (Commission for Architecture and the Built Environment, 2006). Such design often use method understood as design thinking which combines creative ways of learning about the user's needs and looking for design solutions (Bourgeois-Bougrine et al., 2018).

These nearly identical concepts correspond to the various categories of users, including users defined by restrictions resulting from age-related bodily changes. So, this is a way of approaching the understanding of the problem of potential exclusion by way of bad design, rather than one specific methodology of design. Although design for all/universal design/inclusive design concepts are similar to the idea of AFCCs, they are not exclusive to only the elderly. According to the premises of inclusive design, the result should reflect the diversity of users, they combine to create a comfortable and functional environment for the elderly, disabled, or even small families. That is why when researchers and designers deal with the problems of an ageing society, they increasingly turning to these concepts. As 
such, they not only document their legitimacy in improving the quality of life of seniors, but also reveal the real degree of application of the proposals resulting from them in individual societies and the interest of researchers from around the world (Torku et al., 2020) in developing this concept.

\subsection{New technologies and their importance in age-friendly cities and communities design}

The implementation of the premises of AFCCs should be supplemented with new trends combining design and new (digital, ICTs) technology. According to the review of edited publications from 2011-2018 on the subject of AFCCs (Torku et al., 2020) there has been no research where the main goal would be to show their role in AFCCs. One of the few articles on this subject is an article published in 2019 by Marston and van Hoof (2019). The concept of technology cannot be limited to only one definition. Generally, the term technology can be understood as knowledge, methods, techniques that allow to perform complex processes or to describe a specific technical solution appropriate for given times and level of scientific and technical development.

This article centers on technologies important to support ageing processes and primarily concern solutions in the field of ICTs. These forms of technology hold more potential to improve the lives of seniors than with any other age group (Ramón-Jerónimo et al., 2013). Despite there being limited studies directly assessing the usefulness of ICT with regard to the AFCCs model, it is still possible to extract enough data to make recommendations on how to embed the role of new technologies in these 8-domains. For example (World Health Organization, 2017):

- transport and mobility, e.g. accurate and accessible automated on-trip and pre-trip information with audio and visual information, offering "offline" alternatives for transport planning information and ticketing service, online private ride-sharing schemes, e-bikes;

- housing - new technologies could help to protect health, daily digital reminders (for medication), provide a sense of security, etc.;

- social inclusion - enable maintaining contact with others, provide support or even first aid, are opportunities for exchange information with friends. ICT also allows for in work engagement and online skills development;

- domain of communication and information can be seen as increasing senior's usage of electronic equipment, such as mobile telephones, the design of bank and ticket machines with large buttons and big lettering, and most importantly, wide public access to computers and the Internet, especially in public places such as government offices, community centers and libraries (World Health Organization, 2007).

One of the examples, where new technologies are already being implemented to improve the lives of seniors is the concept of smart cities. It is a response not only to the current challenges related to urbanization, but also to the aging of societies.

The smart cities are measured, inter alia, by using innovative and creative solutions in the area of management (Winkowska et al., 2019; Torku et al., Fothcoming), which in practice is related to e.g. access to city resources and the mobility of residents. Therefore, there is a strong relationship between these two concepts. 
Some researchers even claim that AFCCs can be a source of legitimacy for smart city initiatives, and can be seen in every AFCCs domain what in practice means: 1 . Outdoor spaces and buildings - smart environment; 2 . Transportation - smart economy and mobility; 3. Housing - smart economy and living; 4. Social participation - smart people and smart governance; 5 . Respect and social inclusion - smart people, governance and living; 6 . Civic participation and employment - smart people and economy; 7. Communication and information - smart economy and mobility; 8 . Community support and health services - smart governance and living (Torku et al., Forthcoming).

All areas are important, but from the perspective of this article, but special attention should be paid to domain of communication and information. An effective communication system reaches community residents of all ages and does not require additional costs, which is a cardinal principle of creativity in universal design.

Therefore, the presented text is an attempt to show the possibilities of adapting this model, taking into account primarily the aspect of its implementation in the perspective of new technologies. The key in this topic will be to assess the legitimacy of such solutions and compare them with the individual needs, as indicated by Polish elderly people.

\section{Research methodology and sample characteristics}

The main goal of the research ${ }^{1}$ was to discover how Polish seniors assess the use of new technologies in public and private spaces with regard to their real needs.

In accordance with the methodology, there are three main points of relevance with which to rate the use of new technologies by seniors with respect to their needs and expectations. They are:

- their current importance for seniors (related to current age, social situation and health);

- the current state of solutions within their city;

- their expected importance at a later life (related to the growing consequences of ageing).

Although the original research involved the analysis of 40 different solutions in implementing the idea of AFCCs (grouped in seven categories: urban space, public transport, construction and functional solutions, housing and health, social integration, safe and security, new technological solutions), this article focuses on nine selected examples - practical and available solutions used in public and private space with application of new technologies, such as:

1. The pedestrian crossing motion sensor - adjusting to individuals' abilities;

2. Direct 24-hour access to medical services (by phone or by device above the bed telecare);

3. Health monitoring via telemedicine wrist band;

4. Bus timetable access via mobile phone;

\footnotetext{
${ }^{1}$ The research project Inhabitation in an Urban Environment: Needs for Space Adaptation and Opinion about Existing Solutions - From the Perspective of Seniors in Rybnik City, Poland was carried out in 2019 especially for the 17th Polish Sociological Congress in Wrocław, Poland (presented during the plenary session: "Design and Ageing Society: Activation, Co-Production and Social Inclusion of Seniors").
} 
5. Mobile location sharing;

6. Access to mobile phone updates about current events in the city;

7. Access to bus stop induction loops;

8. Online grocery purchase and delivery;

9. Remote or phone application control of home lights and appliances.

The research was carried out in the city of Rybnik - one of the cities located in Southern Poland. The city of Rybnik is interesting for several reasons:

- it is among the thirty largest Polish cities - both in terms of occupied area $(148 \mathrm{~km} 2$, putting it in 16th place in the country and the 5th in the region) and the number of inhabitants (138 thousand putting it in 25th place in the country and 8th place in the region);

- Rybnik has an ageing population. The share of people in their post-productive age is increasing year by year (21\% in 2019), the demographic dependency ratio is also increasing (in 2019, there were 36 post-productive age residents per 100 productive age residents), and level of the population growth per 1000 inhabitants is in decline (in 2019 reached 0.0 what gives a middle position in the country and region);

- like in most Polish cities, Rybnik has a negative migration balance recorded (in 2019 it is minus 3.3 per 1 thousand population, which gives 40 th place in the country and eighth in the region);

- due to the intensive industrialization of the region since the second half of the 20th century, the city of Rybnik experienced intensive urbanization;

- as a result of urbanization taking place not only around the city center, but also in its areas, Rybnik consists of many urban districts, some of which are located peripherally to the center;

- there is also the fact that Rybnik is a rich city. Revenue per one inhabitant reaches PLN 6700, and expenses over PLN 7000 (this gives 25th place in the country and the second in the region) (Urząd Statystyczny w Katowicach, 1995-2019, 19952020).

The study was conducted among 108 seniors who participated in meetings of the senior clubs and the University of the Third Age, located in Rybnik. The data was collected by using the auditorium questionnaire - adapted to the perceptive capabilities of the elderly and implemented with support of the researcher if needed. This turned out to be the right choice of research technique because it was convenient and friendly for the respondents.

The majority $(78.7 \%)$ of the respondents were women, and there was significant age diversity among them. Seniors below 64 accounted $23.1 \%$ of the sample, 65 to 69 years accounted for $34.3 \%$ of respondents, 70 to 74 years $-25 \%$, 75 years and more $-15.7 \%$ ( $1.9 \%$ of people age was not specified). The surveyed group was dominated by people with vocational education (42.6\%); the second largest category of education were people with secondary level of education (37\%). People with primary or incomplete primary education constituted $8.3 \%$ of the respondents, with higher education $-7.4 \%$ (in $4.6 \%$ of cases it was not possible to determine education). Almost one third of respondents (32.4\%) lead a one-person household. $43.5 \%$ of seniors lived with a partner. Others $-19.4 \%$ lived most often with children, slightly less often with other family members, least often - with people outside the family $(4.6 \%$ of respondents did not answer the question). Most of the respondents lived in multi-family 
buildings (61.1\%); other persons most often in single-family or two-family buildings $(21.3 \%)$ or in other buildings $(0.9 \%)$. In $16.7 \%$ of respondents no response was obtained. The respondents turned out to be diverse due to a subjective assessment of their health situation. Exactly half described this situation as "neither good nor bad", 37\% considered "rather good" and $6.5 \%$ as "rather bad". Extreme assessments of the health situation were given by a few people $-2.8 \%$ considered her "very good" and "very bad" - $1.9 \%$ (another $1.9 \%$ is no data).

This research hopes to broaden the current articulated knowledge on the real needs of older people as well as to shed new light on many issues related to adapting public and private spaces for older people. Only some of these results are presented below, but such a sample underscores both the legitimacy of and need to address the topic.

\section{Results, discussion and interpretation}

\subsection{New technologies solutions in perspective of the current importance for seniors}

As already mentioned above, one part of the questionnaire was related to the perception of new technologies in perspective to the current needs of seniors participating in the study. They were asked to determine the level of importance of selected technologies in their current life ("very important"; "rather important"; "less important or not important" or "difficult to say").

The frequency distribution of answers referring to the 9 solutions considered is presented in Table 1. Relatively the most often, solutions (1), (2) and (3) were recognized as "very important". The first of them (1) directly concerns urban space, and is dedicated not only to the elderly, but to all pedestrians on the streets. The next two are more related to the quality of health and safety. It is also worth emphasizing that (2) and (3) solutions enable only individual use and they are mainly dedicated to single elderly people, especially those who are running a one-person household.

Solutions requiring the use of a smartphone or the Internet (solutions 4-9) turned out to be significantly less important (the level of "very important" answers comparable or even lower than the "less important..." answers). That is why they are more eager to reach for new solutions that actually provide ease, convenience or comfort to their lives.

When considering the age of respondents in the distribution of their responses, one notices a significant difference in the perceived importance of new technology-based solutions with regard to the senior's reality (see Table 2). The first three solutions seem to be almost equally very important for respondents of all ages. Differences in perception arise in relation to solutions that require the use of a smartphone or the Internet (solutions 4-9).

The vast majority of people under the age of 70 recognized these solutions as very important for their current needs and life situation. This is certainly due to the fact that these people most often use the smartphone in everyday life. At the same time, people aged 70 and over, more often consider these technological solutions much less important to them (they chose "rather important..." much more often than "very important", and a large group declared "...not important"). Unfortunately, if they use the smartphone less often, they are not able to learn and convince themselves to use these technological solutions. 
Table 1. New technologies' current importance for seniors $(\mathrm{N}=108)$ (source: created by authors)

\begin{tabular}{|c|c|c|c|c|c|c|c|}
\hline 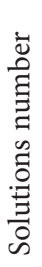 & The new technologies solutions & 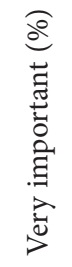 & 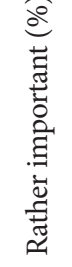 & 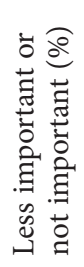 & 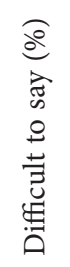 & 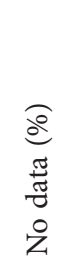 & 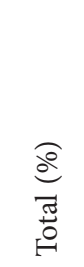 \\
\hline 1 & $\begin{array}{l}\text { The pedestrian crossing motion sensor - } \\
\text { adjusting to individuals' abilities }\end{array}$ & 75.9 & 15.7 & 2.8 & 3.7 & 1.9 & 100.0 \\
\hline 2 & $\begin{array}{l}\text { Direct } 24 \text {-hour access to medical services (by } \\
\text { phone or by device above the bed - telecare) }\end{array}$ & 67.6 & 18.5 & 2.8 & 7.4 & 3.7 & 100.0 \\
\hline 3 & Health monitoring via telemedicine wrist band & 50.9 & 26.9 & 6.5 & 7.4 & 8.3 & 100.0 \\
\hline 4 & Bus timetable access via mobile phone & 34.3 & 27.8 & 22.2 & 11.1 & 4.6 & 100.0 \\
\hline 5 & Mobile location sharing & 33.3 & 34.3 & 12.0 & 13.0 & 7.4 & 100.0 \\
\hline 6 & $\begin{array}{l}\text { Access to mobile phone updates about current } \\
\text { events in the city }\end{array}$ & 21.3 & 28.7 & 19.4 & 20.4 & 10.2 & 100.0 \\
\hline 7 & Access to bus stop induction loops & 19.4 & 32.4 & 14.8 & 25.9 & 7.4 & 100.0 \\
\hline 8 & Online grocery purchase and delivery; & 16.7 & 32.4 & 31.5 & 13.0 & 6.5 & 100.0 \\
\hline 9 & $\begin{array}{l}\text { Remote or phone application control of home } \\
\text { lights and appliances }\end{array}$ & 15.7 & 26.9 & 28.7 & 19.4 & 9.3 & 100.0 \\
\hline
\end{tabular}

Table 2. New technologies' current importance for seniors - determined by age $(\mathrm{N}=106)$ (source: created by authors)

\begin{tabular}{|c|c|c|c|c|c|c|c|c|c|}
\hline 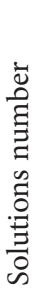 & $\begin{array}{c}\text { The new technologies } \\
\text { solutions }\end{array}$ & 品 & 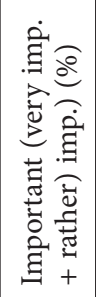 & 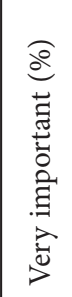 & 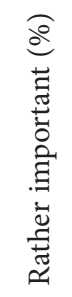 & 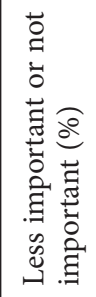 & 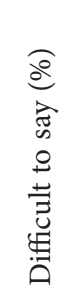 & 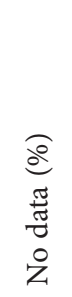 & $\frac{\substack{\varrho \\
\frac{\pi}{0} \\
0}}{0}$ \\
\hline \multirow[t]{2}{*}{1} & \multirow{2}{*}{$\begin{array}{l}\text { The pedestrian crossing } \\
\text { motion sensor - adjusting to } \\
\text { individuals' abilities }\end{array}$} & below 70 & 95.2 & 75.8 & 19.4 & 3.2 & 1.6 & 0.0 & 100.0 \\
\hline & & 70 and older & 86.4 & 75.0 & 11.4 & 2.3 & 6.8 & 4.5 & 100.0 \\
\hline \multirow[t]{2}{*}{2} & \multirow{2}{*}{$\begin{array}{l}\text { Direct } 24 \text {-hour access to } \\
\text { medical services (by phone } \\
\text { or by device above the bed - } \\
\text { telecare) }\end{array}$} & below 70 & 85.5 & 61.3 & 24.2 & 4.8 & 8.1 & 1.6 & 100.0 \\
\hline & & 70 and older & 86.4 & 75.0 & 11.4 & 0.0 & 6.8 & 6.8 & 100.0 \\
\hline \multirow[t]{2}{*}{3} & \multirow{2}{*}{$\begin{array}{l}\text { Health monitoring via } \\
\text { telemedicine wrist band }\end{array}$} & below 70 & 83.9 & 56.5 & 27.4 & 6.5 & 8.1 & 1.6 & 100.0 \\
\hline & & 70 and older & 68.2 & 40.9 & 27.3 & 6.8 & 6.8 & 18.2 & 100.0 \\
\hline \multirow[t]{2}{*}{4} & \multirow{2}{*}{$\begin{array}{l}\text { Bus timetable access via } \\
\text { mobile phone* }\end{array}$} & below 70 & 72.6 & 37.1 & 35.5 & 21.0 & 4.8 & 1.6 & 100.0 \\
\hline & & 70 and older & 45.5 & 27.3 & 18.2 & 25.0 & 20.5 & 9.1 & 100.0 \\
\hline \multirow[t]{2}{*}{5} & \multirow[t]{2}{*}{ Mobile location sharing } & below 70 & 71.0 & 35.5 & 35.5 & 14.5 & 11.3 & 3.2 & 100.0 \\
\hline & & 70 and older & 61.4 & 27.3 & 34.1 & \begin{tabular}{|l|}
9.1 \\
\end{tabular} & 15.9 & 13.6 & 100.0 \\
\hline
\end{tabular}




\begin{tabular}{|c|c|c|c|c|c|c|c|c|c|}
\hline 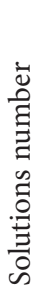 & $\begin{array}{c}\text { The new technologies } \\
\text { solutions }\end{array}$ & $\stackrel{0}{<}$ & 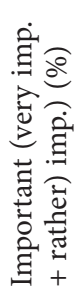 & 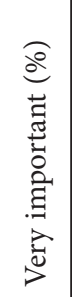 & 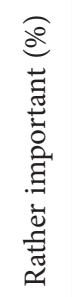 & 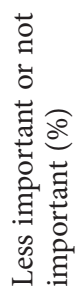 & 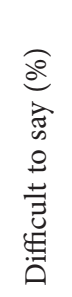 & 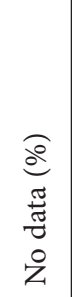 & 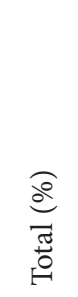 \\
\hline \multirow[t]{2}{*}{6} & \multirow{2}{*}{$\begin{array}{l}\text { Access to mobile phone } \\
\text { updates about current events } \\
\text { in the city }\end{array}$} & below 70 & 56.5 & 21.0 & 35.5 & 16.1 & 22.6 & 4.8 & 100.0 \\
\hline & & 70 and older & 38.7 & 20.5 & 18.2 & 25.0 & 18.2 & 18.2 & 100.0 \\
\hline \multirow[t]{2}{*}{7} & \multirow{2}{*}{$\begin{array}{l}\text { Access to bus stop induction } \\
\text { loops }\end{array}$} & below 70 & 66.1 & 25.8 & 40.3 & 12.9 & 16.1 & 4.8 & 100.0 \\
\hline & & 70 and older & 31.8 & 9.1 & 22.7 & 18.2 & 38.6 & 11.4 & 100.0 \\
\hline \multirow[t]{2}{*}{8} & \multirow{2}{*}{$\begin{array}{l}\text { Online grocery purchase and } \\
\text { delivery }^{\star}\end{array}$} & below 70 & 56.4 & 17.7 & 38.7 & 35.5 & 8.1 & 0.0 & 100.0 \\
\hline & & 70 and older & 36.4 & 11.4 & 25.0 & 27.3 & 20.5 & 15.9 & 100.0 \\
\hline \multirow[t]{2}{*}{9} & \multirow{2}{*}{$\begin{array}{l}\text { Remote or phone application } \\
\text { control of home lights and } \\
\text { appliances }^{*}\end{array}$} & below 70 & 50.0 & 17.7 & 32.3 & 32.3 & 14.5 & 3.2 & 100.0 \\
\hline & & 70 and older & 29.6 & 11.4 & 18.2 & 25.0 & 27.3 & 18.2 & 100.0 \\
\hline
\end{tabular}

Note: ${ }^{\star}$ Chi2 $(3, \mathrm{n}=106) ; \mathrm{p}<0.05$ (four categories was used: 1. "very important", 2. "rather important", 3. "Less important or no important", 4. "Difficult to say/no data".

It may also be indicated that, the differences between people with a one-person household and people living together with others turned out to be not strong. Also, the type of inhabited building (multi-family or single- or two-family houses) did not generate significant differences in the distribution of respondents' answers.

\subsection{New technology solutions in the perspective of assessing the current state in the city}

The next part of the study, directly concern the respondents' opinions on the current state in the city from the perspective of assessing the new technology solutions. Respondents were asked the question: "How do you assess your city due to the level of meeting a specific need or application of a specific solution?" and could choose between such answers: "it is advisable to pay much more attention to the issue in the city", "it is advisable to pay a little more attention to the issue in the city", "no additional actions are needed - it is as it should be" and "difficult to say".

Compared to the previous issue (concerning the current life situation of seniors), the order of selected solutions changed only slightly. Similarly, "much more attention" was expected more often to solutions dedicated especially to the elderly, not requiring special skills of use and oriented on health care and safety related to health condition, what is shown in Table 3.

The assessment of new technologies important for the city was related to the assessment of new technologies currently important for seniors. This relation also concerned solutions related to the use of new technologies. As the Figure 1 shows, seniors rated the city slightly less critically in relation to their own needs in terms of solutions 1 and 5, more critically in relation to the city than their current needs would indicate, while they referred to solution 7 . 
Table 3. The current state of technological solutions within their city $(\mathrm{N}=108)$ (source: created by authors)

\begin{tabular}{|c|c|c|c|c|c|c|c|}
\hline 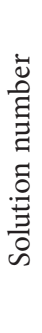 & The new technologies solutions & 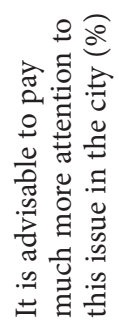 & 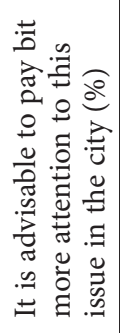 & 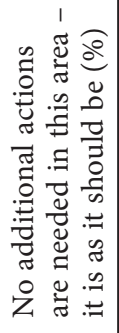 & 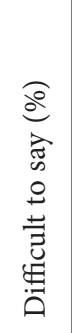 & 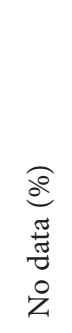 & 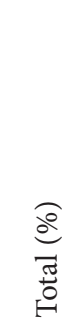 \\
\hline 1 & $\begin{array}{l}\text { The pedestrian crossing motion sensor - } \\
\text { adjusting to individuals' abilities }\end{array}$ & 54.6 & 28.7 & 6.5 & 5.6 & 4.6 & 100.0 \\
\hline 2 & $\begin{array}{l}\text { Direct } 24 \text {-hour access to medical services (by } \\
\text { phone or by device above the bed - telecare) }\end{array}$ & 58.3 & 16.7 & 1.9 & 10.2 & 13.0 & 100.0 \\
\hline 3 & $\begin{array}{l}\text { Health monitoring via telemedicine wrist } \\
\text { band }\end{array}$ & 41.7 & 27.8 & 5.6 & 9.3 & 15.7 & 100.0 \\
\hline 4 & Bus timetable access via mobile phone & 29.6 & 28.7 & 16.7 & 14.8 & 10.2 & 100.0 \\
\hline 5 & Mobile location sharing & 25.0 & 30.6 & 15.7 & 16.7 & 12.0 & 100.0 \\
\hline 7 & Access to bus stop induction loops & 24.1 & 22.2 & 8.3 & 33.3 & 12.0 & 100.0 \\
\hline 6 & $\begin{array}{l}\text { Access to mobile phone updates about } \\
\text { current events in the city }\end{array}$ & 19.4 & 33.3 & 16.7 & 14.8 & 15.7 & 100.0 \\
\hline 9 & $\begin{array}{l}\text { Remote or phone application control of } \\
\text { home lights and appliances }\end{array}$ & 18.5 & 26.9 & 21.3 & 17.6 & 15.7 & 100.0 \\
\hline 8 & Online grocery purchase and delivery & 15.7 & 32.4 & 24.1 & 13.0 & 14.8 & 100.0 \\
\hline
\end{tabular}
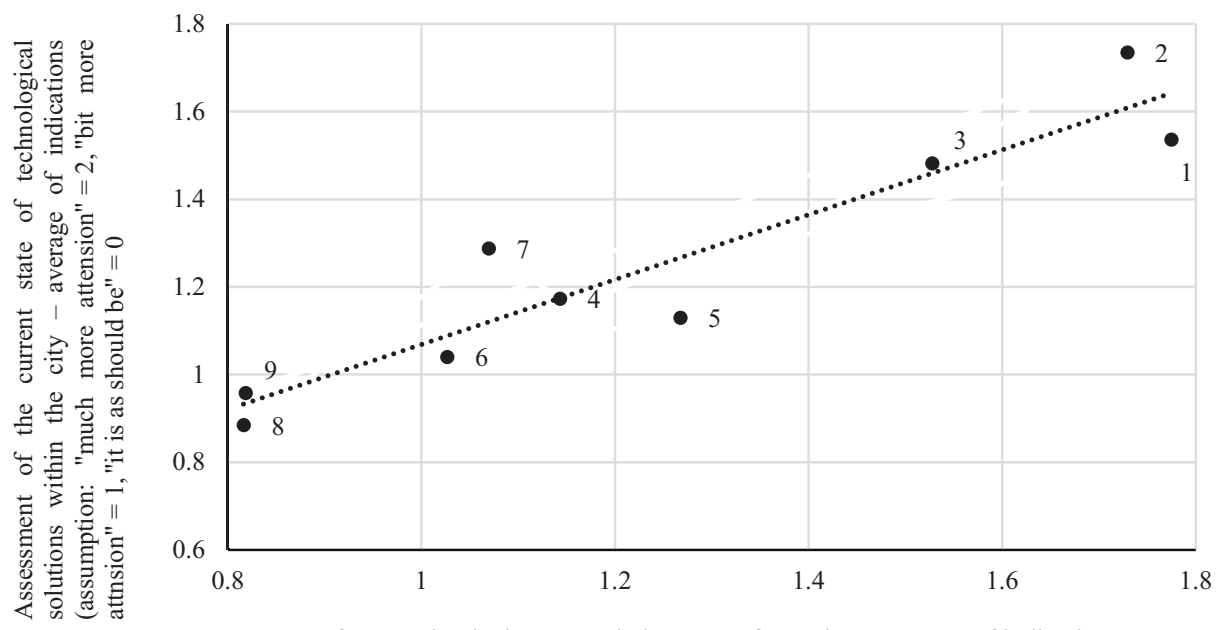

Assesment of new technologies currently important for seniors - average of indications (assumption: "very important" = 2, "rather important" = 1, "less important/not important" = 0

Figure 1. Relations between assessment of the current state of technological solutions within their city and assessment of new technologies currently important for seniors - the averages of indications (source: created by authors) 
The data shown in the Figure 1 indicate only general trends about the relation between seniors needs and expectations for solutions in the city. However, in Table 4 we show the detailed results about this relation at the level of individual choices. "Adequate" choices mean that the answers indicate the same level of importance. Simultaneously, "inadequate" choices mean that there is a discrepancy between feeling the needs for individual preferences and assessing the city.

"Adequate" choices related mainly to solutions such as (3) and (7). The least "adequate" choices related to solutions such as (4) and (6). In many solutions, the percentage of respondents who were more focused on change in the city than for their own current needs was similar to the percentage of those more oriented for own current needs than for a change in the city. The "inadequate" choices concerned solutions (1), (5), (7). The first (1) was seen as a solution more important from the point of view of the current needs of seniors than from the point of view of changes that should be done in the city. Slightly smaller disproportion, although in the same direction, concerned solution (5). The need to make changes in the city turned out to be slightly stronger than the individual current needs of seniors in the case of solution (7).

Table 4. Relations between assessment of the current state of technological solutions within their city and assessment of new technologies currently important for seniors - "adequate" and "inadequate" selection (source: created by authors)

\begin{tabular}{|c|c|c|c|c|c|c|c|c|}
\hline \multirow[b]{2}{*}{ 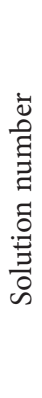 } & \multirow[b]{2}{*}{ The new technologies solutions } & \multicolumn{3}{|c|}{$\begin{array}{l}\text { "Adequate" } \\
\text { selection (\%) }\end{array}$} & \multicolumn{2}{|c|}{$\begin{array}{l}\text { "Inadequate" } \\
\text { selection }(\%)\end{array}$} & \multicolumn{2}{|c|}{ Total } \\
\hline & & 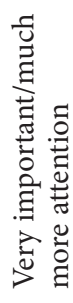 & 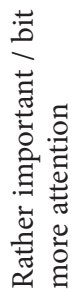 & 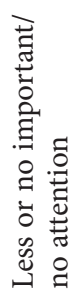 & 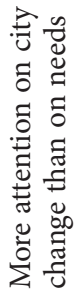 & 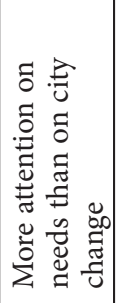 & Z & $a^{\circ}$ \\
\hline 1 & $\begin{array}{l}\text { The pedestrian crossing motion sen- } \\
\text { sor - adjusting to individuals' abilities }\end{array}$ & 55.9 & 7.5 & 2.2 & 6.5 & 28.0 & 93 & 100.0 \\
\hline 2 & $\begin{array}{l}\text { Direct } 24 \text {-hour access to medical } \\
\text { services (by phone or by device above } \\
\text { the bed - telecare) }\end{array}$ & 66.7 & 14.1 & 1.3 & 10.3 & 7.7 & 78 & 100.0 \\
\hline 3 & $\begin{array}{l}\text { Health monitoring via telemedicine } \\
\text { wrist band }\end{array}$ & 47.4 & 25.0 & 6.6 & 7.9 & 13.2 & 76 & 100.0 \\
\hline 4 & Bus timetable access via mobile phone & 22.7 & 18.7 & 12.0 & 22.7 & 24.0 & 75 & 100.0 \\
\hline 5 & Mobile location sharing & 28.2 & 29.6 & 11.3 & 11.3 & 19.7 & 71 & 100.0 \\
\hline 6 & $\begin{array}{l}\text { Access to mobile phone updates about } \\
\text { current events in the city }\end{array}$ & 18.8 & 25.0 & 10.9 & 21.9 & 23.4 & 64 & 100.0 \\
\hline 7 & Access to bus stop induction loops & 31.4 & 25.5 & 13.7 & 17.6 & 11.8 & 51 & 100.0 \\
\hline 8 & Online grocery purchase and delivery & 16.2 & 25.0 & 22.1 & 16.2 & 20.6 & 68 & 100.0 \\
\hline 9 & $\begin{array}{l}\text { Remote or phone application control of } \\
\text { home lights and appliances }\end{array}$ & 16.9 & 25.4 & 22.0 & 18.6 & 16.9 & 59 & 100.0 \\
\hline
\end{tabular}

Note: The calculations did not include respondents who - at the level of individual solutions - did not answer at least one question or chose at least once the "difficult to say" option. 


\subsection{New technology solutions from the perspective of expected importance at a later life}

The last part of the study presented here concerns perception of the new technology-based solutions with regard to the future and the ageing process. Respondents were asked the question: "Do you think the importance of new technology solutions will increase in the future for your needs?" and could choose between such answers: "will be more important", "will be just as important as now", "will be less important" and "difficult to say".

For all solutions related to the use of new technologies, the percentage of respondents choosing "more important" was higher than those choosing "less important". So, in the respondents' predictions, the significance of these technologies will increase proportionally to their age advancement. As in previous perspectives - the first three solutions were considered "more important" in the future by the largest part of the respondents. More detailed data are included in Table 5.

For the remaining solutions, the respondents' opinions were divided mainly between those convinced of the growing importance of technologies in the future and those advocating maintaining the current status.

Table 5. The expected importance of new technology in later life (due to ageing $(\mathrm{N}=108)$ (source: created by authors)

\begin{tabular}{|c|c|c|c|c|c|c|c|}
\hline 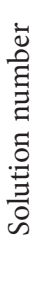 & The new technologies solutions & 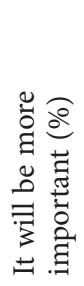 & 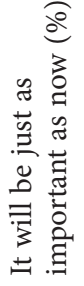 & 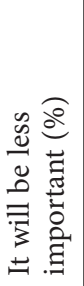 & 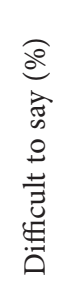 & 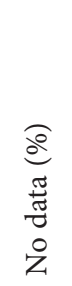 & 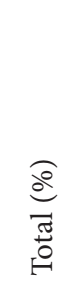 \\
\hline 1 & $\begin{array}{l}\text { The pedestrian crossing motion sensor - } \\
\text { adjusting to individuals' abilities }\end{array}$ & 54.6 & 25.0 & 1.9 & 7.4 & 11.1 & 100.0 \\
\hline 2 & $\begin{array}{l}\text { Direct } 24 \text {-hour access to medical services (by } \\
\text { phone or by device above the bed - telecare) }\end{array}$ & 59.3 & 19.4 & 1.9 & 5.6 & 13.9 & 100.0 \\
\hline 3 & Health monitoring via telemedicine wrist band & 54.6 & 16.7 & 5.6 & 9.3 & 13.9 & 100.0 \\
\hline 5 & Mobile location sharing & 41.7 & 18.5 & 5.6 & 14.8 & 19.4 & 100.0 \\
\hline 4 & Bus timetable access via mobile phone & 33.3 & 29.6 & 12.0 & 13.9 & 11.1 & 100.0 \\
\hline 8 & Online grocery purchase and delivery & 28.7 & 26.9 & 15.7 & 10.2 & 18.5 & 100.0 \\
\hline 9 & $\begin{array}{l}\text { Remote or phone application control of home } \\
\text { lights and appliances }\end{array}$ & 28.7 & 27.8 & 13.0 & 12.0 & 18.5 & 100.0 \\
\hline 7 & Access to bus stop induction loops & 25.9 & 25.0 & 6.5 & 27.8 & 14.8 & 100.0 \\
\hline 6 & $\begin{array}{l}\text { Access to mobile phone updates about current } \\
\text { events in the city }\end{array}$ & 25.9 & 26.9 & 16.7 & 14.8 & 15.7 & 100.0 \\
\hline
\end{tabular}




\section{Conclusions}

Taking into account all the needs and solutions in the overall research, it is worth emphasizing that the solutions that use new technologies compared to other solutions - traditional or commonly used - were generally less frequently indicated as important. However, the diversity in the indications for individual types of solutions was so significant that some of them turned out to be more important than other traditional solutions. This may be a premise to say that seniors are open to technological innovation and seeking creative solutions in urban design.

Referring to current needs and solutions, but also assessing their usefulness in the city and estimating their relevance in the future - seniors focused primarily on solutions that do not require the acquisition of special skills and knowledge in the field of smartphone and Internet use. They pointed to solutions that could be considered specifically designed for seniors, constituting a response to the need for health care and safety related to health condition.

Analyzing the current needs, the most influential indicator was age. Younger seniors more often considered solutions using new technologies to be important than older seniors. The differences were particularly evident in the case of solutions requiring the acquisition of knowledge and skills in the field of use.

Therefore, it should be expected and anticipated the significance of solutions related to the use of technologically advanced solutions will increase in the future - due to an increase in demand born of aptitude. The age of seniors - despite the differences presented - will not cause a drop in interest in these solutions. Referring to future needs, the seniors recognized that solutions using new technologies stand to be of increasing importance.

However, studies have shown, that despite the general agreement between the assessment of solutions important for the city and the assessment of solutions important for seniors, some incongruencies are possible - some solutions in perspective of the current needs of seniors may prove more important than in perspective of assessing solutions in the city, while others - on the contrary -prove to be more important for the city than for seniors personally.

Considering solutions that can improve the quality of life of seniors in the city, the spatial specificity of cities should be considered. It is in this dimension that there may be differences. The research was limited to seniors from the city, which in Poland can be considered a large city, but not a metropolis in which the potential for adaptation of innovative solutions may be greater. A city of over 100,000, especially with an industrial character, however, generates a lot of needs in the field of space arrangement, which satisfying in a traditional way may not be sufficient, which seems to have been noticed by the surveyed seniors. A different distribution of responses should also be expected for seniors living in rural areas. The difference between these realities and urban ones will certainly influence the opinions of the surveyed residents.

The studied area allowed to estimate the adaptation potential of seniors who, due to the industrial specificity of the city, do not have high cultural capital. Certainly, however, it is difficult to consider seniors from the examined city as representative for all seniors in the country, as well as in the city itself. The above reflection prompts the expansion of research in the future both in the spatial dimension (diagnosing the needs of seniors also in another, 
less urbanized area) and in the social dimension (diagnosing the needs of seniors who do not participate in organizations).

In the future, it is also worth extending the subject scope of research not only to new technological solutions, which will become easier to access over time, but also to such solutions that may be necessary and expected as the rise of various types of civilization threats, such as epidemics, environment pollution.

\section{References}

Barbosa Neves, B., \& Amaro, F. (2012). Too old for technology? How the elderly of Lisbon use and perceive ICT. The Journal of Community Informatics, 8(1). https://doi.org/10.15353/joci.v8i1.3061

Barbosa Neves, B., Amaro, F., \& Fonseca, J. R. S. (2013). Coming of (Old) Age in the digital age: ICT usage and non-usage among older adults. Sociological Research Online, 18(2), 22-35. https://doi.org/10.5153/sro.2998

Bourgeois-Bougrine, S., Latorre, S., \& Mourey, F. (2018). Promoting creative imagination of non-expressed needs: exploring a combined approach to enhance design thinking. Creativity Studies, 11(2), 377-394. https://doi.org/10.3846/cs.2018.7184

Broady, T., Chan, A., \& Caputi, P. (2010). Comparison of older and younger adults' attitudes towards and abilities with computers: implications for training and learning. British Journal of Educational Technology, 41(3), 473-485. https://doi.org/10.1111/j.1467-8535.2008.00914.x

Buffel, T., Phillipson, Ch., \& Scharf, Th. (2012). Ageing in urban environments: developing "age-friendly" cities. Critical Social Policy, 32(4), 597-617. https://doi.org/10.1177/0261018311430457

Cammen, van der T. J. M., Albayrak, A., Voûte, E., \& Molenbroek, J. F. M. (2017). New horizons in design for autonomous ageing. Age and Ageing, 46(1), 11-17.

Carpenter, B. D., \& Buday, S. (2007). Computer use among older adults in a naturally occurring retirement community. Computers in Human Behavior, 23(6), 3012-3024.

https://doi.org/10.1016/j.chb.2006.08.015

Cattaneo, M., Malighetti, P., \& Spinelli, D. (2016). The impact of university of the third age courses on ICT adoption. Computers in Human Behavior, 63, 613-619. https://doi.org/10.1016/j.chb.2016.05.087

Charness, N., \& Boot, W. R. (2009). Aging and information technology use: potential and barriers. Current Directions in Psychological Science, 18(5), 253-258. https://doi.org/10.1111/j.1467-8721.2009.01647.x

Chiu, Ch.-J., \& Liu, Ch.-W. (2017). Understanding older adult's technology adoption and withdrawal for elderly care and education: mixed method analysis from national survey. Journal of Medical Internet Research, 19(11). https://doi.org/10.2196/jmir.7401

Cody, M. J., Dunn, D., Hoppin, Sh., \& Wendt, P. 1999. Silver surfers: training and evaluating internet use among older adult learners. Communication Education, 48(4), 269-286. https://doi.org/10.1080/03634529909379178

Commission for Architecture and the Built Environment. (2006). The Principles of inclusive design (they include you). https://www.designcouncil.org.uk/sites/default/files/asset/document/the-principlesof-inclusive-design.pdf

Czaja, S. J., Boot, W. R., Charness, N., \& Rogers, W. A. (2019). Designing for older adults: principles and creative human factors approaches. Series: Human Factors and Aging Series. CRC Press. https://doi.org/10.1201/b22189

Damodaran, L., Olphert, W., \& Phipps, S. (2013). Keeping silver surfers on the crest of a wave: older people's ICT learning and support needs. Working with Older People, 17(1), 32-36.

https://doi.org/10.1108/13663661311312566 
Eurostat. (2020). Individuals - internet use. https://ec.europa.eu/eurostat/web/products-datasets/-/ isoc_ci_ifp_iu

Friemel, Th. N. (2016). The digital divide has grown old: determinants of a digital divide among seniors. New Media and Society, 18(2), 313-331. https://doi.org/10.1177/1461444814538648

Fuente Suárez, de la L. A. (2013). Architecture: the design of an experience. LIMES: Borderland Studies, 6(1), 1-20.

Gallistl, V., Rohner, R., Seifert, A., \& Wanka, A. (2020). Configuring the older non-user: between research, policy and practice of digital exclusion. Social Inclusion, 8(2), 233-243. https://doi.org/10.17645/si.v8i2.2607

Gawron, G., \& Rojek-Adamek, P. (2017). Aging in place: design w obronie wieku. Kultura Popularna, 2(52), 4-18. https://doi.org/10.5604/01.3001.0010.7046

Hogeboom, D. L., McDermott, R. J., Perrin, K. M., Osman, H., \& Bell-Ellison, B. A. (2010). Internet use and social networking among middle aged and older adults. Educational Gerontology, 36(2), 93-111. https://doi.org/10.1080/03601270903058507

Hussain, D., Ross, P., \& Bednar, P. (2017). The perception of the benefits and drawbacks of internet usage by the elderly people. In C. Rossignoli, F. Virili, \& S. Za (Eds.), Digital technology and organizational change: reshaping technology, people, and organizations towards a global society (pp. 199-212). Series: Lecture Notes in Information Systems and Organisation. Vol. 23. Springer.

Kamin, S. T., Lang, F. R., \& Beyer, A. (2017). Subjective technology adaptivity predicts technology use in old age. Gerontology, 63(4), 385-392. https://doi.org/10.1159/000471802

Lee, B., Chen, Y., \& Hewitt, L. (2011). Age differences in constraints encountered by seniors in their use of computers and the interne. Computers in Human Behavior, 27(3), 1231-1237. https://doi.org/10.1016/j.chb.2011.01.003

Lelkes, O. (2013). Happier and less isolated: internet use in old age. Journal of Poverty and Social Justice, 21(1), 33-46. https://doi.org/10.1332/175982713X664047

Lifshitz, R., Nimrod, G., \& Bachner, Y. G. (2018). Internet use and well-being in later life: a functional approach. Aging and Mental Health, 22(1), 85-91. https://doi.org/10.1080/13607863.2016.1232370

Mace, R. L. (1998). Universal design in housing. Assistive Technology: The Official Journal of RESNA, 10(1), 21-28. https://doi.org/10.1080/10400435.1998.10131957

Mace, R. L., Young, L. C., \& Telles, C. (1980). Planner's guide to barrier free meetings. Barrier Free Environment and Harold Russell Association.

Marston, H. R., \& Hoof, van J. (2019). "Who doesn't think about technology when designing urban environments for older people?" A case study approach to a proposed extension of the WHO's age-friendly cities model. International Journal of Environmental Research and Public Health, 16. https://doi.org/10.3390/ijerph16193525

Nimrod, G. (2014). The benefits of and constraints to participation in seniors' online communities. Leisure Studies, 33(3), 247-266. https://doi.org/10.1080/02614367.2012.697697

Ramón-Jerónimo, M. A., Peral-Peral, B., \& Arenas-Gaitán, J. (2013). Elderly persons and internet use. Social Science Computer Review, 31(4), 389-403. https://doi.org/10.1177/0894439312473421

Reisdorf, B. C., \& Groselj, D. (2017). Internet (non-)use types and motivational access: implications for digital inequalities research. New Media and Society, 19(8), 1157-1176. https://doi.org/10.1177/1461444815621539

Schulz, R., Wahl, H.-W., Matthews, J. T., Vito Dabbs, De A., Beach, S. R., \& Czaja, S. J. (2015). Advancing the aging and technology agenda in gerontology. The Gerontologist, 55(5), 724-734. https://doi.org/10.1093/geront/gnu071

Shapira, N., Barak, A., \& Gal, I. (2007). Promoting older adults' well-being through internet training and use. Aging and Mental Health, 11(5), 477-484. https://doi.org/10.1080/13607860601086546 
Taha, J., Sharit, J., \& Czaja, S. (2009). Use of and satisfaction with sources of health information among older internet users and nonusers. The Gerontologist, 49(5), 663-673. https://doi.org/10.1093/geront/gnp058

Torku, A., Chan, A. P. C., \& Yung, E. H. K. (Forthcoming). Implementation of age-friendly initiatives in smart cities: probing the barriers through a systematic review. Built Environment Project and Asset Management, (ahead-of-print).

Torku, A., Ping Chuen Chan, A., \& Hiu Kwan Yung, E. (2020). Age-friendly cities and communities: a review and future directions. CORRIGENDUM. Ageing and Society, First View, 1-5. https://doi.org/10.1017/S0144686X2000094X

Urząd Statystyczny w Katowicach. (1995-2020). Ludność, ruch naturalny i migracje w województwie śląskim w 2019 r. https://katowice.stat.gov.pl/publikacje-i-foldery/ludnosc/ludnosc-ruch-naturalnyi-migracje-w-wojewodztwie-slaskim-w-2019-r-,2,18.html\#

Urząd Statystyczny w Katowicach. (1995-2019). Statystyczne Vademecum Samorządowca - Miasta Rybnik. https://katowice.stat.gov.pl/statystyczne-vademecum-samorzadowca/

Wagner, N., Hassanein, K., \& Head, M. (2010). Computer use by older adults: a multi-disciplinary review. Computers in Human Behavior, 26(5), 870-882. https://doi.org/10.1016/j.chb.2010.03.029

Wanka, A., \& Gallistl, V. (2018). Doing age in a digitized world - a material praxeology of ageing with technology. Frontiers in Sociology, 3. https://doi.org/10.3389/fsoc.2018.00006

Wilson, C. (2018). Is it love or loneliness? Exploring the impact of everyday digital technology use on the wellbeing of older adults. Ageing and Society, 38, 1307-1331. https://doi.org/10.1017/S0144686X16001537

Winkowska, J., Szpilko, D., \& Pejić, S. (2019). Smart city concept in the light of the literature review. Engineering Management in Production and Services, 11(2), 70-86. https://doi.org/10.2478/emj-2019-0012

World Health Organization. (2021). About the global network for age-friendly cities and communities. https://extranet.who.int/agefriendlyworld/who-network/

World Health Organization. (2017). Age-friendly environments in europe: a handbook of domains for policy action. https://apps.who.int/iris/bitstream/handle/10665/334251/9789289052887-eng.pdf

World Health Organization. (2007). Global age-friendly cities: a guide. https://www.who.int/ageing/publications/Global_age_friendly_cities_Guide_English.pdf 